\title{
Design and Evaluation of Dadu Canal Lining for Sustainable Water Saving
}

\author{
Ashfaque A. Memon ${ }^{1}$, Khalifa Q. Leghari ${ }^{1}$, Agha F. H. Pathan ${ }^{1}$, Kanya L. Khatri ${ }^{2}$, \\ Sadiq A. Shah ${ }^{2}$, Kanwal K. Pinjani ${ }^{3}$, Rabia Soomro ${ }^{2}$, Kameran Ansari ${ }^{1}$ \\ ${ }^{1}$ Department of Civil Engineering, Mehran UET, Jamshoro, Sindh, Pakistan \\ ${ }^{2}$ Department of Civil Engineering, Mehran UET Khairpur Campus, Sindh, Pakistan \\ ${ }^{3}$ Water Resources Division, National Engineering Services, Lahore, Pakistan \\ Email: rajaln@yahoo.com, ashfaquememon144@gmail.com
}

Received April 25, 2013; revised May 27, 2013; accepted June 20, 2013

Copyright (c) 2013 Ashfaque A. Memon et al. This is an open access article distributed under the Creative Commons Attribution License, which permits unrestricted use, distribution, and reproduction in any medium, provided the original work is properly cited.

\begin{abstract}
Pakistan livelihood depends on agriculture and so for this on irrigation system. The irrigation system in Sindh province depends on three barrages. The canals off taking from these three barrages irrigate 5.5 million hectares of agriculture land. Sukkur Barrage, which is the oldest one, irrigates more than 2.0 million hectares of land. The Dadu Canal off taking from Sukkur barrage is an earthen canal. A huge amount of irrigation water is lost from the canal in the form of seepage from banks and bed. It is estimated that 40 to 50 per cent of water is lost between the canal head works to the farm-gate. The seepage from the canal creates twin problems of salinity and water logging consequently a large agriculture land has gone out of use, and this process is continued particularly in Sindh. Lining of Canals is considered an effective solution to this problem. But lining of canals in Sindh is a great issue as canals will need to be closed long enough to deprive the farmers at least one crop season and the farmers are unable to pay this price for canal. Therefore, in this study, the Dadu Canal is proposed to be redesigned as an adjacent lined canal which involves design of cross section for various lining options at locations where changes in the hydraulic conditions occur at cross regulators and fall structures. The proposed lining is preferred to be plain cement concrete lining which is selected after investigating local conditions. Quantity and cost estimation at selected RDs (Reduced Distance) proved feasible and significant in long term functioning of Dadu Canal.
\end{abstract}

Keywords: Dadu Canal; Concrete Lining; Canal Design; Lining Evaluation; Sustainable Water Saving

\section{Introduction}

Indus basin irrigation system (IBIS), being one of the world's largest irrigation systems, encompasses 12,676 $\mathrm{km}, 33,884 \mathrm{~km}$ and 122,268 km length of canals at Primary, Secondary and Tertiary levels, respectively [1]. Along with a number of operational problems in IBIS, high rate of seepage occurs while conveyance of approximately 0.123 Million Hectare Meter (MHM) annually [2-6]. Due to excess seepage losses through canals along a lot of agricultural land water table has turned into within one meter depth. Such a serious scenario has resulted into considerable decline in yields of all crops except that of rice [7]. Furthermore, joint adverse effect of water logging and consequent salinity is more substantial than that of water logging only [7]. Hence, it is stated that in Pakistan there is large and cost-effective capacity to enhance water deliveries to agricultural farms by reducing conveyance losses while flow through canal sys- tem $[4,8]$.

As a usual trend along river banks, irrigated agriculture indicated the era of development of human civilization in Sindh also. Early agriculture involving mainly food production changed slowly to modern agriculture through a continuous evolution of agriculture technologies. The present irrigation system in Sindh depends on three barrages namely Sukkur, Kotri and Guddu constructed in 1932, 1955 and 1962 respectively. Except Akram wah (canal) off taking from Kotri Barrage, all other canals are earthen canals. Large amount of irrigation water is lost from these canals in the form of seepage from banks and bed. It is estimated that 40 to 50 per cent of water is lost between the canal head works to the croplands [9].

Prabhata et al. [10] recommend that canals of new irrigation project in arid or semi-arid regions must be lined to avoid chances of abundant seepage in case of dry soil 
and deep groundwater table. Lining of canals is shown a good solution to this problem worldwide. Lining of canals in Sindh is a great matter as canals will need to be closed long enough to and farmers may lose enough crop production which is imperative for their livelihood and nobody is ready to give them subsidy of this loss. The irrigation application rates within the farms are also high because of reliance on the conventional flood irrigation. With the passage of time, water as a commodity is becoming more and more precious. Above all it is a finite source. This high percentage of wastage, therefore, cannot be afforded for long time. Wastage of water through poor infrastructure or poor water management constitutes a major issue related to the water resources of Pakistan.

Another aspect of this issue is the productivity of the farms against per cusec of irrigation water. Pakistan has a much lower rate of production. The irrigation efficiency, therefore, needs to be enhanced. In view of the huge (around 45 to 50 per cent) losses of irrigation water between canal-heads and the farm gate, water conservation should be accorded a high priority. Lining of Canals and water courses should be taken in hand more vigorously.

\section{Dadu Canal}

\subsection{Water Availability}

Dadu canal has been designed for a normal discharge of 89.2 cumec at the head. Main crops are cotton, sugarcane, wheat, rice, fruits and vegetables. Water availability of the Dadu Canal is highly variable due to stochastic nature of flow. Average annual availability on the basis of 5year canal diversion at the canal head and at farm gate is 0.174 MHM and 0.092 MHM respectively, which shows a significant water loss of 0.082 MHM [11].

\subsection{Crop Water Requirements}

The net crop water requirements of 0.4, 0.85, 1.8, 2.0 and $0.5 \mathrm{~m}$ were used for wheat, cotton, rice, sugarcane and fodder crops respectively [9]. These five major crops cover more than $80 \%$ of the total cropped area of the canal and consume $81 \%$ of total water needed for total crop consumptive requirement of the cropped area. This includes: wheat (12.8\% of total), cotton (15.9\% of total), rice $(28.3 \%$ of total), sugarcane (15\% of the total) and fodder (6.8\% of the total). Total water requirements for Kharif crops and Rabi crops are 176 HM (Hectare-Meter) [9].

\subsection{Alignment}

Total length of Dadu Canal is $212 \mathrm{~km}$. The alignment of Dadu Canal has a regime section. It originates from the Sukkur barrage, along right bank of river Indus, passes through the districts of Sukkur, Larkana and Dadu running parallel to the Indus highway N55. Main cities/ towns near the canal are Bagarji, Madeji, Naudero, Larkana, Dokri, Badah village, Mehar, Radhan village, Sita road village and Dadu. The canal is accessible through the district road bridges (DRBs) and village road bridges (VRBs) from most of the above mentioned towns. Moreover, there are many hydraulic structures and road bridges on canal which provide interconnectivity to both the embankments of the canal. However at some places there can be constraints for passage of larger vehicles. Topography of the canal sites is characterized by flat lands, waterlogged in most of the reaches. Basic parameters are given in Table $\mathbf{1}$.

\section{Lining and Remodeling}

According to Streeter [12] the prime parameters of hydraulic efficiency, practicability, and economy should be considered while using uniform flow formula to design a lined canal. The lining of an existing canal invariably involves remodeling of the section. The reasons are to maintain flow levels and command due to difference in Manning's coefficient between unlined and lined material to improve deteriorated canal sections before proceeding with lining and to provide a firm sub-base for application of lining.

Different lining materials are listed by Sharma and Chawla [13]. Amongst various conventional types of lining Cement concrete lining are considered as most suitable because of its long life, durability, structural stability, resistance to erosion, high permissible velocity, etc. Besides the high construction cost of Cement concrete lining, there occurs some seepage due to expansion/contraction of joints. Cement concrete lining, the most commonly used type of lining, consists a layer of cement concrete placed on a well prepared and compacted sub-base. The recommended thickness of lining as per IS: 387319192 is given in Table 2.

\section{Design Methodology}

The design methodology involves design of cross section

Table 1. Basic parameters of Dadu canal.

\begin{tabular}{ccc}
\hline Sr.No. & Parameters & Description \\
\hline 1 & Type & Perennial \\
2 & Length (km) & 212 \\
3 & Gross Command Area (hectares) & 222.967 \\
4 & CCA (Hectares) & 201.810 \\
5 & Design Discharge (cumec) & 89.2 \\
6 & Actual Discharge (cumec) & 124 \\
8 & No. of Channels & 112 \\
9 & No. of Outlets & 2145 \\
\hline
\end{tabular}

Source: operation and maintenance manual, ipd, government of Sindh. 
Table 2. Thickness of cement concrete lining.

\begin{tabular}{cccccc}
\hline $\begin{array}{c}\text { Canal discharge } \\
\text { (cumec) }\end{array}$ & \multicolumn{2}{c}{$\begin{array}{c}\text { Water depth } \\
(\mathrm{m})\end{array}$} & \multicolumn{2}{c}{$\begin{array}{c}\text { Lining thickness } \\
(\mathrm{cm})\end{array}$} \\
\hline \multicolumn{2}{c}{ Up to 5.0} & \multicolumn{2}{c}{ Up to 1.0} & \multicolumn{2}{c}{5} \\
5.0 & 50.0 & 1.0 & 2.5 & 5 & 7.6 \\
50.0 & 199.8 & 2.5 & 4.5 & 7.6 & 10.2 \\
199.8 & 299.6 & 4.5 & 6.6 & 10.2 & 12 \\
299.6 & 699.4 & 6.6 & 9.1 & 12 & 15.2 \\
\hline
\end{tabular}

at the locations where changes in the hydraulic conditions occur, e.g. at cross regulators/fall structures.

\subsection{Design Discharge}

Dadu Canal was originally designed in 1932 for a discharge of 89.2 cumec (Table 3). Over the years, the flows have been increased to 124 cumec and the estimated data show that the design discharges were proposed up to 152 cumec (Table 4).

To fix appropriate value of discharge in Dadu canal, data were collected from following two sources:

1) Sindh water Resources Development and Management Investment Program-Program Report, "Irrigation”.

2) Prepared Design Statement of Dadu Main Canal (Table 5).

To avoid discrepancies in these data cumulative dis-

Table 3. Design statement of selected reaches of Dadu canal (Design Data, 1932).

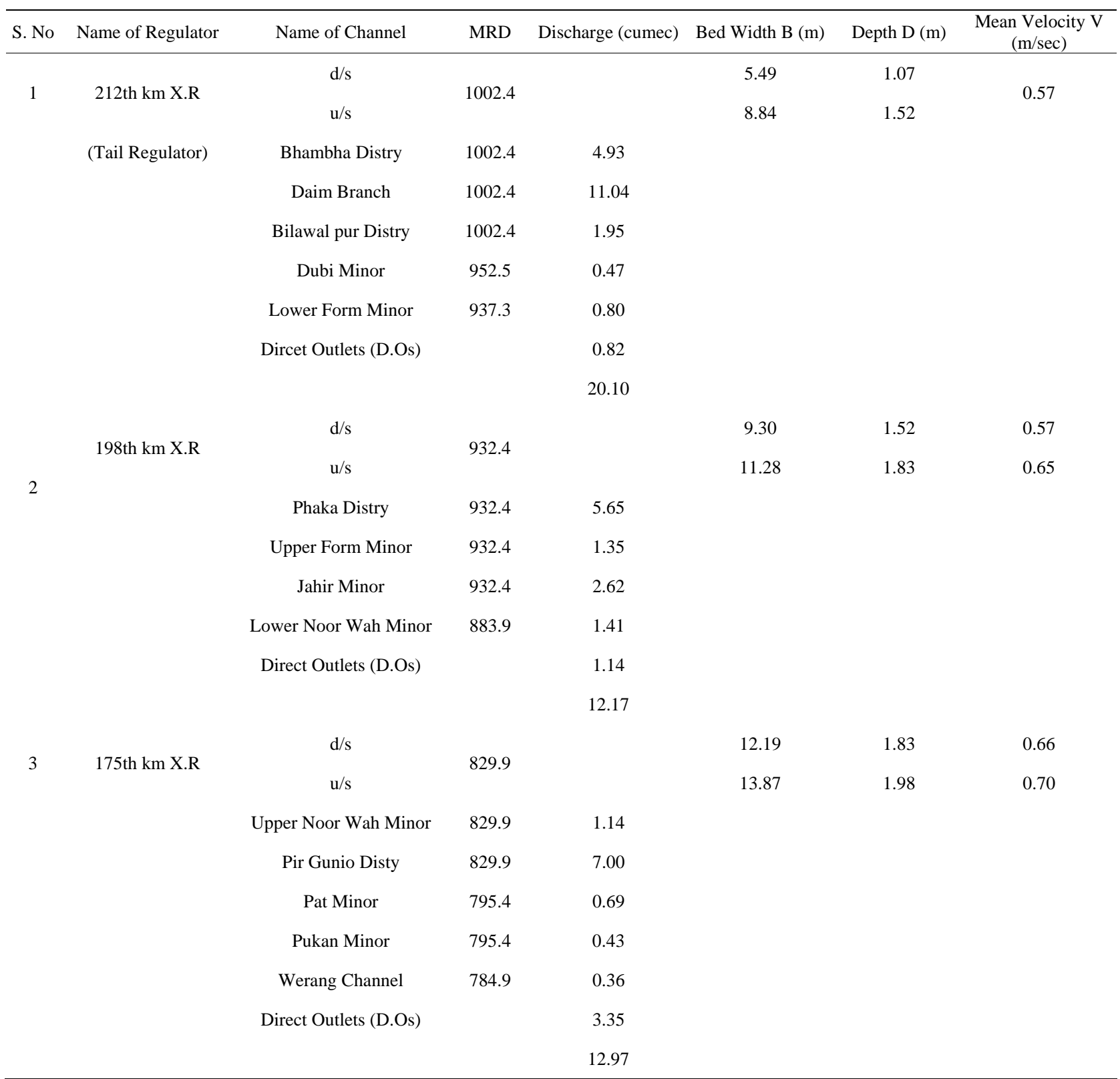


Table 4. Proposed design statement of dadu main canal.

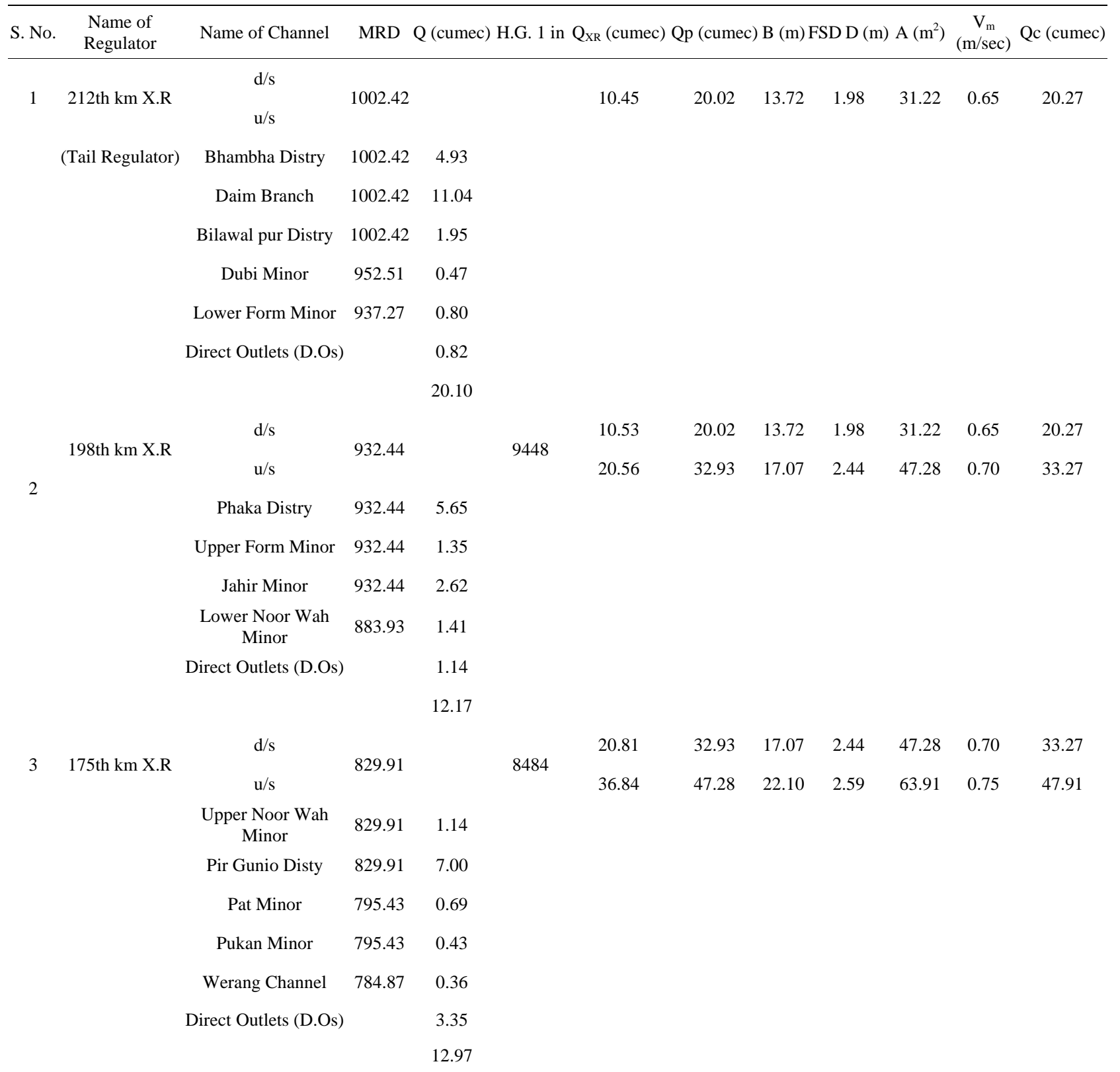

Q = Discharge to distributary; B = Bed Width; A = Flow Area; Vm = Mean Velocity; Qc = Calculated Discharge; QXR = Discharge at Cross Regulator; FSD = Full Supply Depth; N8 H.G = Hydraulic Gradient

charge of the Dadu Canal at Sukkur Headwork is calculated (Table 6) and compared with the headwork discharge as provided in the data. The selection for the design discharge is made from the most relevant data as compared to the headwork discharge. An additional flow of $15 \%$ is included in the design discharge to accommodate future increase or any intermittent operational requirements.

The details of these data are presented in Table 7. The data at serial number 1 above, sum up to only 76 cumec, showing a short coming of $50 \%$ in the total discharge of
152 cumec as given in the Table 5. The design discharges from data at serial number 2, show 130 cumec after summation of discharges from each minor/distributary and 152 cumec listed separately as "calculated discharge".

The design discharges are based on the calculations made in the Design Statement of Dadu Main Canal (Table 3$)$.

\subsection{Section Design}

Following the usual approach adopted by various inves 
Table 5. Prepared design statement of Dadu canal w.r.to existing data.

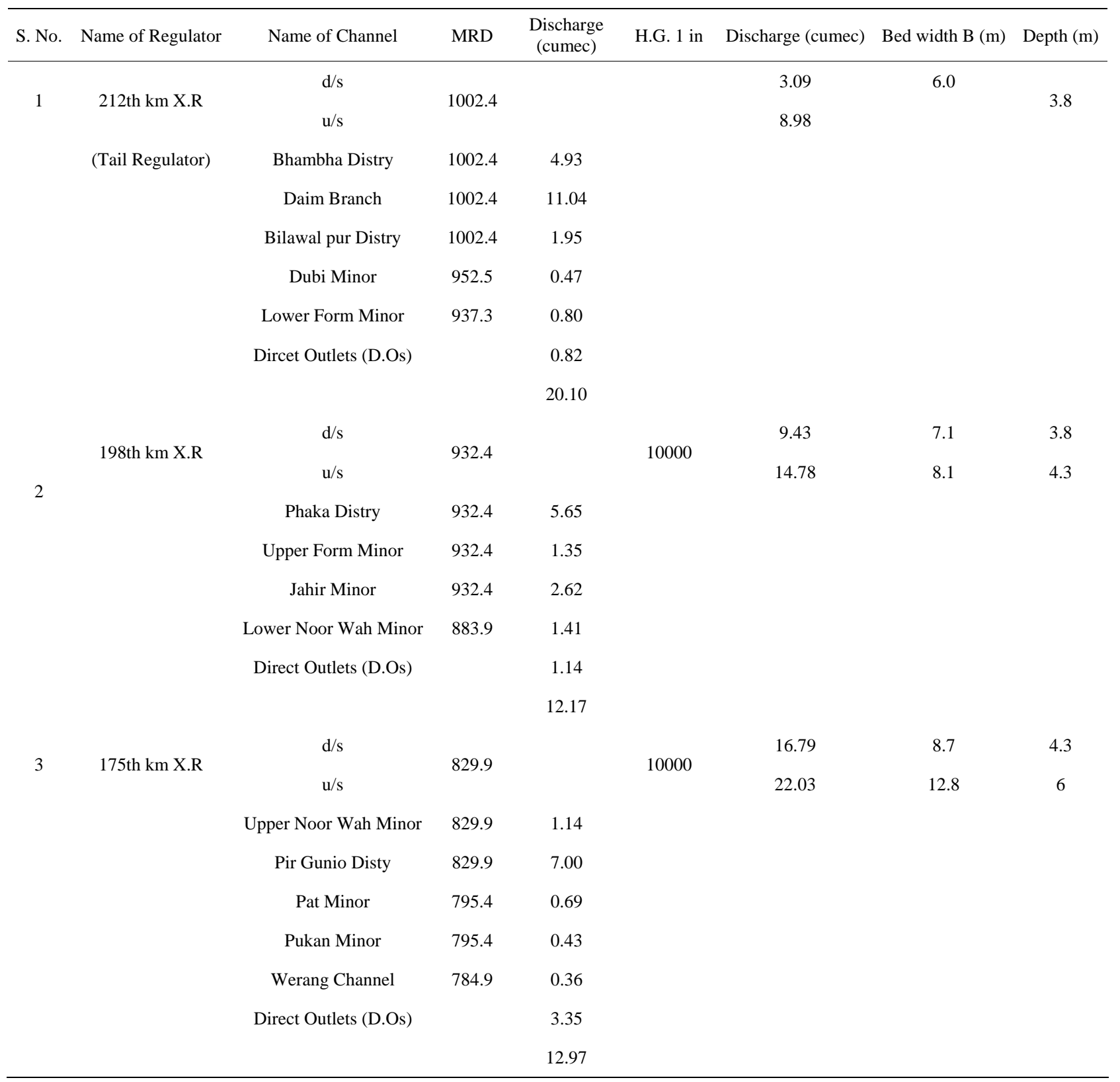

tigators [14-16], in this case the section design for lining option is also based on Manning's formula:

$$
V=\frac{1.486}{n} R^{2 / 3} S^{1 / 2}
$$

where $V$ is velocity of flow (ft/sec); $n$ is Manning's coefficient; $S$ is longitudinal hydraulic slope or canal bed slope (ft per $\mathrm{ft}$ ); $R$ is hydraulic radius $(\mathrm{ft})=\mathrm{A} / \mathrm{P} ; A$ is area of the flow section $\left(\mathrm{ft}^{2}\right)$, and $P$ is wetted perimeter $(\mathrm{ft})$.

\subsection{Manning's Coefficient}

Different characteristics, to make a lined canal section hydraulically most economical, suggested by Chow [17],
French [18] and Guo and Hughes [19], include permeability, Manning's coefficient, durability, cost of construction and maintenance, etc. The permeability of material determines absorption losses and the Manning's coefficient determines the carrying capacity of the channel. Weathering is caused by disruptive action of temperature variation, alternate freezing and thawing, and wetting and drying. The alkali soil causes corrosion of concrete and this can be prevented by the application of sulphate resistant cement (SRC). Cost of construction would vary with the locality and the availability of various materials. The thickness of lined section would depend upon the lining material, the side slope and the existence of hy 
Table 6. Comparative statement of dadu canal.

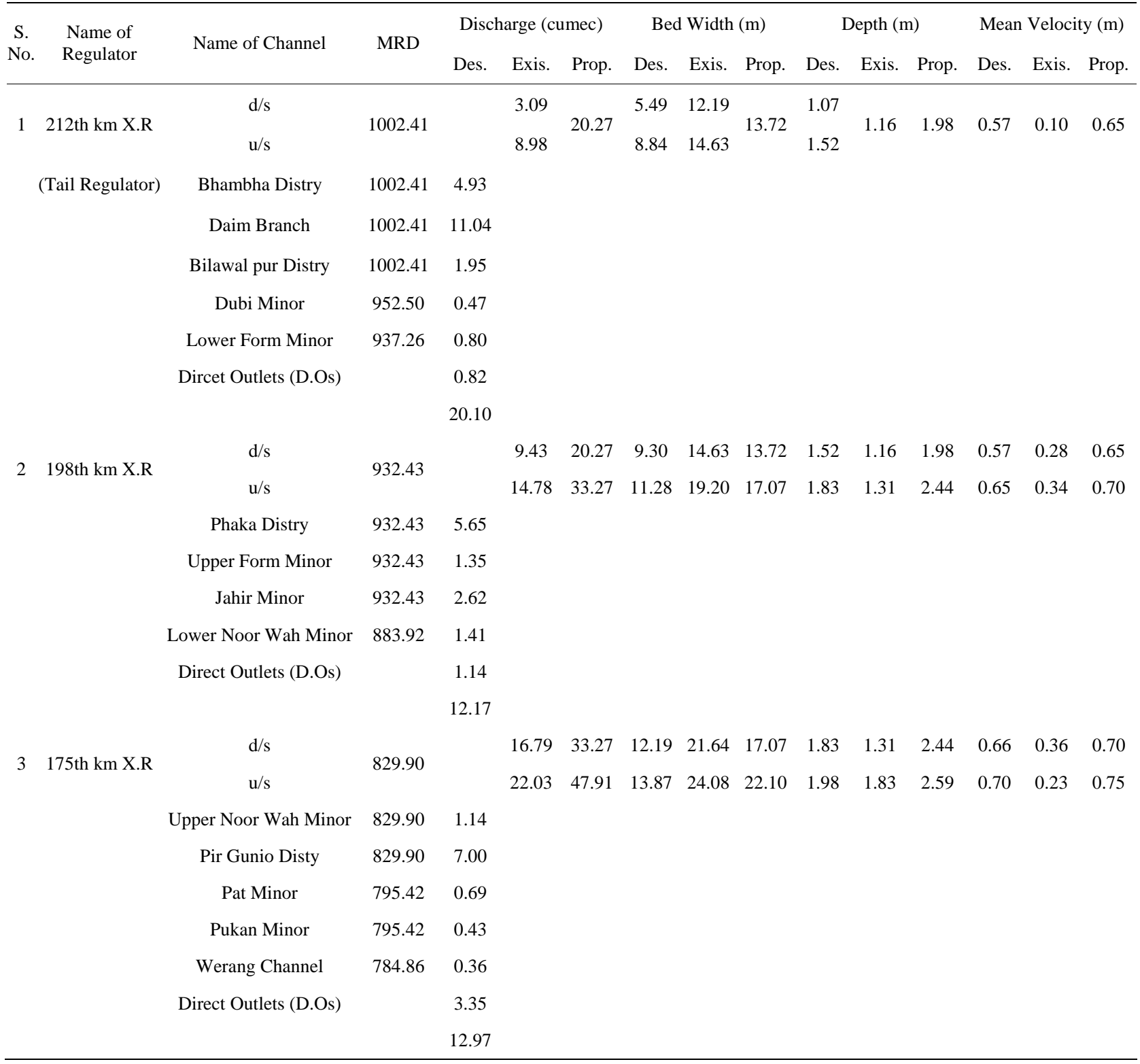

dro-static pressure. There should be proper drainage system to prevent failure due to back pressure.

Concrete lining is durable and, if laid properly, the absorption losses are reduced by 95\%. The Manning's coefficient is low and in view of high permissible velocities, the section is reduced. The construction is carried out in panels and grooves are provided to prevent cracks due to shrinkage and alternate expansion and contraction. Oil paper, crude oil, 1:6 cement plaster or 1:4 cement sand slurry are used at the top of sub grade to avoid its becoming spongy and permeable.

\subsection{Canal Section Properties}

The remodeling of canal section imposes certain restric- tion on the selection of various dimensions; the last designed section dictating most of the values like longitudinal slope, full supply depth and full supply levels. These parameters and the values adopted considering the above points are detailed below.

\subsection{Depth of Flow}

The excessive widening of the existing canal section provides a possibility of selecting a larger bed width with a reduced water depth. In some reaches the silting of canal bed compensates for the reduction in the depth with raised bed levels. The resulting lowering of full supply level, is therefore not so different when compared with full supply levels of last design. A slight reduction in full 
Table 7. Proposed Discharges shown at Barrage Headworks, Cross Regulators and Tail Regulator.

\begin{tabular}{ccc}
\hline RD & Discharge (Cusecs) & At Downstream of Structure \\
\hline $0+000$ & 5378 & Sukkur Barrage Headworks \\
$19+597$ & 5265 & 39 mile Naudero Cross Regulator \\
$250+600$ & 5063 & 51 mile Pir Sher Cross Regulator \\
$283+405$ & 4482 & 57 mile Pandabad Cross Regulator \\
$331+992$ & 4497 & 67 mile Sonahri Cross Regulator \\
$383+460$ & 4127 & 77 mile Tatri Cross Regulator \\
$420+534$ & 3717 & 95 mile Waha Cross Regulator \\
$473+630$ & 3564 & 95 mile Cross Regulator \\
$546+000$ & 1692 & 109 mile Cross Regulator \\
$611+830$ & 1175 & 123 mile Cross Regulator \\
$657+750$ & 716 & 132 mile Tail Regulator \\
\hline
\end{tabular}

supply level has been allowed in the design to reduce the extent of the works required for remodeling of the section. The head ponds created upstream of cross regulators provides control of the required full supply levels for feeding into minors and distributaries. The effects of lowering in the full supply depth, at locations away from the head ponds, will be checked to ensure supplies from direct outlets.

The design with reduced flow depth for same flows, results in increased wetted perimeter and a subsequent increase in the cost of expensive lining. The changes in full supply depth are therefore kept to a minimum. The bed widths are selected between the maximum available due to widening of canals and minimum required for maintaining the desired supply depth.

\subsection{Side Slopes}

Side slope is provided on the consideration of angle of repose of the bank material as it results in a stable bank under dry conditions. The following side slopes are adopted for the lining under dry condition option and the embankment material (sand fill) used in the remodeling:

1) Concrete lined, new parallel canal $2 \mathrm{H}: 1 \mathrm{~V}$

(Utilizing minimum right of way, achieve stability under drawdown conditions and provide ease in construction)

2) Unlined diversion channel In cutting $1 \mathrm{H}: 1 \mathrm{~V}$

In filling $1.5 \mathrm{H}: 1 \mathrm{~V}$

\subsection{Canal Longitudinal Slope}

A lined canal can have steeper longitudinal slopes (Lslopes) than unlined canals, as higher velocities which may cause erosion of unlined canals, are not a problem.
The existing canals have a large number of cross regulators with combination of fall structures, having upstream and downstream controlling levels. The existing bed levels suggest uneven L-slope as well as reverse slopes in small reaches due to uneven silting. The silting is mainly limited to upper reaches and scouring at lower reaches. In reaches having scouring in almost the entire reach, the same L-slopes are adopted as that of last design, and the bed levels are also kept the same.

\subsection{Freeboard}

Considering the size and discharge of the canal, the value of free board may be roughly taken as one-sixth of flow depth. Recommended values of freeboard are as follows

\begin{tabular}{cc}
\hline Discharge (cumec) & Free Board (m) \\
\hline 450 to 255 & 0.91 \\
255 to 170 & 0.84 \\
$<170$ & 0.76 \\
\hline
\end{tabular}

The freeboard provided in the design includes $80 \%$ of the above values for the freeboard plus calculated depths required for passing additional 15\% flows. The resulting freeboard is then checked for the depths required during various stages of remodeling, allowing 50\% of the freeboard for any such possible increase.

\subsection{Velocity of Flow}

Since, higher permissible velocities reduce silt deposition in the bed of lined canal and all the silt is passed on to the lower reaches and into the distributaries and minors, it necessitates lining of minors and distributaries to avoid rising of bed levels which may affect the command of the irrigation network.

To limit this phenomenon to a minimum there is no drastic increase in the existing velocities in the remodeled section. The present velocities of around $1.0 \mathrm{~m} / \mathrm{sec}$ are generally increased by $15 \%$ to $25 \%$, to remain below $2.2 \mathrm{~m} / \mathrm{sec}$. However in some upper reaches with heavy silting of canal bed, the longitudinal slope has been increased to minimize the required remodeling work. In such reaches, up to $40 \%$ increase in the existing flow velocities are allowed with maximum velocity not to exceed $1.4 \mathrm{~m} / \mathrm{sec}$.

The velocity of flows during remodeling is also checked. Velocities greater than $1.1 \mathrm{~m} / \mathrm{sec}$ are not considered suitable for remodeled section with available nearby material or graded soil, before application of lining.

\section{Hydraulic Design Worksheets}

The design for remodeled sections downstream of cross regulator or fall structures is done through MS Excel 
worksheet developed for this purpose. There are three main reaches of Dadu Canal first at "123rd Mile X.R", second at "85th Mile X.R", and third at "57th Mile X.R". The worksheet includes design for the plain concrete lining with recommended value of " $\mathrm{n}$ " as 0.017 .

\subsection{Design Procedure}

The design worksheet of selected reaches, as shown in Table 4, is calculated adopting following procedure.

For the assumed value of bottom width of channel section, discharge $(\mathrm{Q})$ is calculated using continuity equation. The computed discharge is compared with required discharge $\left(\mathrm{Q}_{\mathrm{req}}\right)$; if both discharges are equal it means that the design of selected section is correct and if not then revise the bottom width.

\subsection{Checking of Design Parameters}

The checking of designed worksheet parameters (i.e. Bed width, Flow area, Wetted perimeter, Hydraulic radius, and Flow velocity) has been done by using "Flow Master Software (2009)". One of the trial sections and final remodeled sections computed by the software are shown in Figures 1 and 2, respectively. These hydraulic design parameters are compared with those at design stage and existing data as shown in Table 6.

\section{Quantity and Cost Estimation}

Preliminary cost estimates have been prepared for the

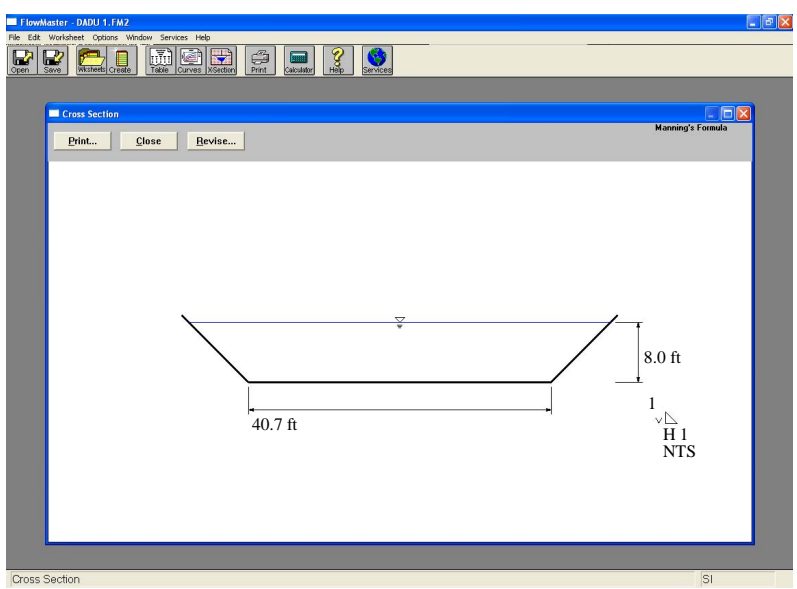

Figure 1. The simplest version of the designed cross section by Flow Master.

Plain cement concrete lining. For this purpose the quantity of cutting (trimming), backfilling at the sides of the canal and quantity of concrete lining perimeter are worked out. The thickness of $13 \mathrm{~cm}$ is taken for estimateing the concrete quantity having strength of 3000 psi in selected reaches.

\subsection{Quantities}

The quantities of the selected reaches up to MRDs 457, 503, 655, 686, 953 and 983 along the length of canal are worked out in MS EXCEL worksheet as shown in Table 8.

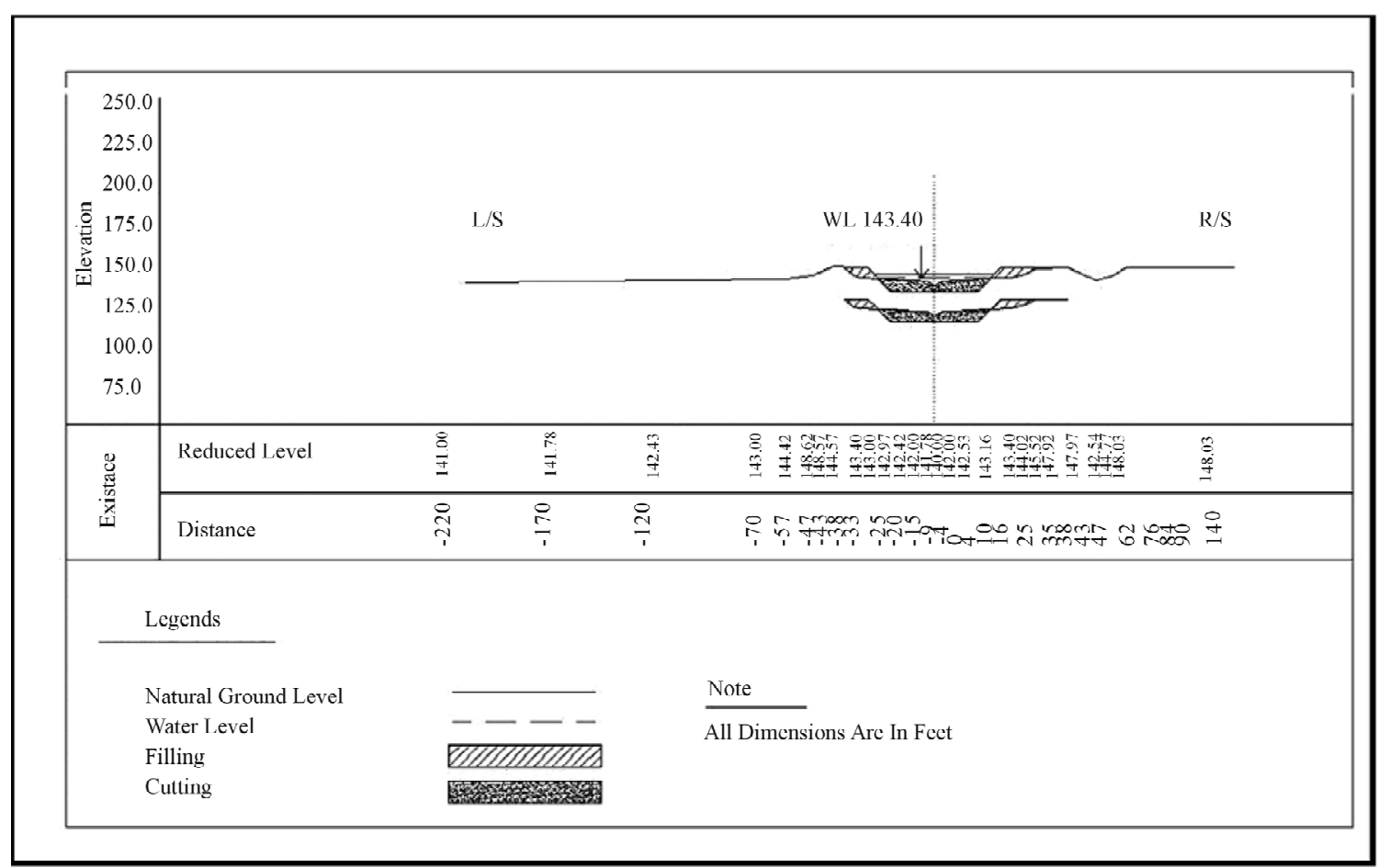

Figure 2. Remodeled cross-section by flow master with complete design. 


\subsection{Cost Estimation}

The cost of the selected reaches as mentioned above are worked out in MS EXCEL worksheet in Millions Rupees as shown in Table 9.

\section{Results and Discussion}

Lining Dadu canal decreases seepage losses from $40 \%$ to $50 \%$, consequently water logging becomes negligible. Conveyance efficiency increases from $70 \%$ to $90 \%$ resulting into significant increase in cropping intensity. Smaller width of lined section increases flow velocity, and that in turn, will reduce silting in canal reach. Lined canal reduces maintenance cost for longer period and improves its performance. Sections designed by MS-EXCEL worksheet are well-matching with those by Flow Master Software, e.g. at 123rd Mile cross regulator the section obtained (shown in Figure 2) is same as that obtained through MS-EXCEL worksheet (as shown in Table 6). The quantity estimation of the material is done very precisely by using AutoCAD.

\section{Conclusion}

As a result of proposed lining of the Dadu canal, seepage losses, water logging, silting and maintenance cost of canal can be significantly decreased, consequently, flow velocity, conveyance efficiency and cropping intensity can be increased. The initial investments over canal lining seem to be very high, but canal lining is a sustainable step which proves to be very economical in terms of long term benefits and for a country like Pakistan; it is very necessary to conserve water for its future.

\section{Recommendations}

All the canals at primary, secondary and tertiary level must be lined step-by-step so as to prevent huge water losses and make the system more and more efficient.

\section{Acknowledgements}

Authors thank to International Water Management Institute (IWMI) Pakistan and particularly appreciate Dr.

Table 8. Quantity estimation of selected sections of Dadu Canal.

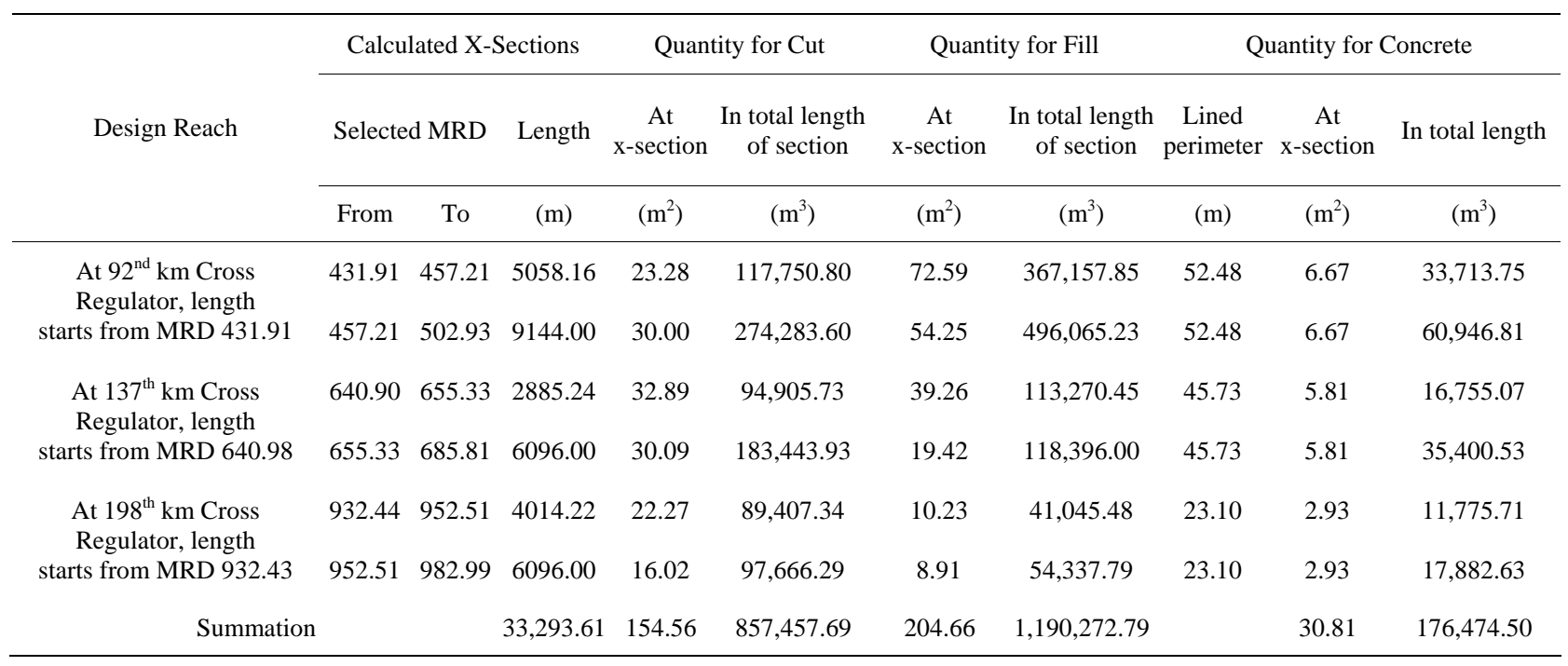

Table 9. Cost Estimation of Dadu Canal.

\begin{tabular}{|c|c|c|c|c|c|}
\hline \multirow{3}{*}{$\begin{array}{l}\text { Item } \\
\text { No: }\end{array}$} & \multirow{3}{*}{ Item Description } & \multirow{3}{*}{$\begin{array}{c}\text { Total Calculated } \\
\text { Quantity } \\
\left(\mathrm{m}^{3}\right)\end{array}$} & \multirow{3}{*}{$\begin{array}{c}\text { Rate } \\
\text { (Rs/Unit) }\end{array}$} & \multirow{2}{*}{\multicolumn{2}{|c|}{ Total Amounts }} \\
\hline & & & & & \\
\hline & & & & (Rs) & (Millions) \\
\hline 1 & $\begin{array}{l}\text { Excavation or cutting(triming) of sand or clay (earth material) at the bed } \\
\text { of canal to maintain bed slope }\end{array}$ & 857,458 & 700 & $600,220,375.6$ & $600,220,376$ \\
\hline 2 & $\begin{array}{l}\text { Providing and placing of plain cement concrete of } 3000 \text { Psi strenght using } \\
\text { Sulphate resistance cement for } 5 \text { inches thick Canal lining }\end{array}$ & 176,474 & 20,000 & 3,529,489,955 & $3529,489,96$ \\
\hline \multirow[t]{2}{*}{3} & $\begin{array}{l}\text { Backfilling of berms of canal sections using the earth material (either } \\
\text { excavated or borrowed) }\end{array}$ & $1,190,273$ & 1500 & 1,785,409,191 & $1,785,409,19$ \\
\hline & & & Total & $5,915,119,523$ & $5,915,119,52$ \\
\hline
\end{tabular}


G.V. Skogerboe, the Ex-Director, IWMI-Pak, for providing experimentation facilities.

\section{REFERENCES}

[1] M. N. Bhutta and N. Ahmad, "Impact of Watercourse Lining plus Measures on Reducing Drainage Requirements,” International Waterlogging and Salinity Research Institute, Lahore, 2006.

[2] WAPDA, "Pakistan Water Sector Strategy,” Vol. 5, Government of Pakistan, Ministry of Water and Power, Lahore, 2002.

[3] A. R. Ghumman, M. A. K. Tarrar and A. A. Tahir, "Investigation of Optimal Use of Canal Water in Pakistan," Proceedings of the International Conference on Water Resources and Arid Environment, 2004, pp. 1-8.

[4] IDWR, "Augmenting Water Resources: Water in Rajasthan," Report of the Expert Committee on Integrated Development of Water Resources, 2005.

[5] M. Arshad, Q. Zaman and A. Madani, "Lining Impact on Water Losses in Watercourses: A Case Study in Indus Basin, Pakistan," Annual Conference of the Canadian Society for Bioengineering, North Vancouver, 13-16 July 2008, pp. 1-12.

[6] S. M. S. Shah, Z. M. Maan and M. K. Sarwar, "Impact of the Alternative Lining of Water Course on Cost and Efficiency," Science, Technology and Development, Vol. 30, No. 4, 2011, pp. 31-38.

[7] M. A. Kahlown and M. Azam, "Individual and Combined Effect of Waterlogging and Salinity on Crop Yields in the Indus Basin,” Journal of International Commission on Irrigation and Drainage, Vol. 51, No. 4, 2002, pp. 329-338. doi:10.1002/ird.62

[8] M. A. Kahlown and W. D. Kemper, "Reducing Water Losses from Channels Using Linings: Costs and Benefits in Pakistan," Agricultural Water Management, Vol. 74, No. 1, 2005, pp. 57-76. doi:10.1016/j.agwat.2004.09.016

[9] I. Hussain, F. Mariker and W. Jehangir, "Productivity and Performance of Irrigated Wheat Farms across Canal Commands in Lower Indus Basin,” International Water Man- agement Institute, Research Report 44, Colombo, 2000.

[10] K. Prabhata, P. K. Swamee, G. C. Mishra and B. R. Chahar, "Minimum Cost Design of Lined Canal Sections," Water Resources Management, Vol. 14, No. 1, 2000, pp. 1-12, Netherlands. doi:10.1023/A:1008198602337

[11] “On Farm Water Management Field Manuals,” Vol. I, II, and III, Ministry of Food, Agriculture and Cooperative, Government of Pakistan, Mid-Year Review, July-December 2008, Planning \& Development Department, Government of Sindh, pp. 1-6.

[12] V. L. Streeter, “Economical Canal Cross Sections,” Transactions of ASCE, Vol. 110, 1945, pp. 421-430.

[13] H. D. Sharma and A. S. Chawla, "Manual of Canal Lining,” Technical Report No. 14, Central Board of Irrigation and Power, New Delhi, 1975.

[14] M. A. Iqbal, M. Raoof and M. Hanif, "Impact of Waterlogging on Major Crop Yields: A Case Study in Southern Punjab,” Journal of Drainage Water Management, Vol. 5, No. 2, 2002, pp. 1-7.

[15] P. Monadjemi, "General Formulation of Best Hydraulic Channel Section,” Journal of Irrigation and Drainage Engineering (ASCE), Vol. 120, No. 1, 1994, pp. 27-35.

[16] P. K. Swamee, "Discussion on General Formulation of Best Hydraulic Channel Section," Journal of Irrigation and Drainage Engineering (ASCE), Vol. 121, No. 2, 1995, p. 222. doi:10.1061/(ASCE)0733-9437(1995)121:2(222)

[17] V. T. Chow, “Open Channel Hydraulics,” McGraw Hill Book Co. Inc., New York, 1973.

[18] R. H. French, “Open Channel Hydraulics,” McGraw Hill Book Co. Inc., New York, 1994.

[19] C. Y. Guo and W. C. Hughes, "Optimal Channel Cross Section with Free Board,” Journal of Irrigation and Drainage Engineering (ASCE), Vol. 110, No. 3, 1984, pp. 304313. doi:10.1061/(ASCE)0733-9437(1984)110:3(304)

[20] P. K. Swamee and K. G. Bhatia, "Economic Open Channel Section," Journal of Irrigation Power (CBI\&P, NewDelhi), Vol. 29, No. 2, 1972, pp. 169-176. 